\title{
KONTRIBUSI PEMANFAAT AN PERPUSTAKAAN SEKOLAH TERHADAP HASIL BELAJAR ILMU PENGETAHUAN SOSIAL (IPS) PADA SISWA KELAS VIII SMP NEGERI 2 SING ARAJA TAHUN AJARAN 2016-2017
}

\author{
Komang Tyas Nugraheni \\ Jurusan Pendidikan Ekonomi \\ Universitas Pendidikan Ganesha \\ Singaraja, Indonesia \\ e-mail: nugraheni.tyas@ymail.com
}

\begin{abstract}
Abstrak
Penelitian ini bertujuan untuk mengetahui (1) hubungan antara pemanfaatan perpustakaan sekolah terhadap hasil belajar IPS pada siswa kelas VIII SMP Negeri 2 Singaraja tahun ajaran 20162017, dan (2) kontribusi perpustakaan sekolah terhadap hasil belajar IPS pada siswa kelas VIII SMP Negeri 2 Singaraja tahun ajaran 2016 - 2017. Penelitian ini adalah jenis penelitian korelasional. Data dikumpulkan dengan metode dokumentasi, kuesioner, dan observasi. Subjek dalam penelitian ini siswa kelas VIII 1 - VIII 6 SMP Negeri 2 Singaraja. Analisis data yang digunakan adalah analisis korelasi Product Moment, dan koefisien determinasi $\left(R^{2}\right)$. Hasil penelitian menunjukkan bahwa (1) ada hubungan (korelasi) yang positif antara pemanfaatan perpustakaan sekolah terhadap hasil belajar IImu Pengetahuan Sosial (IPS) pada siswa kelas VIII SMP Negeri 2 Singaraja Tahun Ajaran 2016 2017. Hal ini ditunjukkan dengan perolehan rhitung $0.274>r_{\text {tabel }} 0.1637$ dengan tingkat signifikansi $5 \%$. (2) kontribusi pemanfaatan perpustakaan sekolah (X) terhadap hasil belajar IPS (Y) adalah sebesar 0.075 hal ini berarti pemanfaatan perpustakaan sekolah memiliki hubungan sebesar $0.075(7.5 \%)$ terhadap hasil belajar IPS pada siswa kelas VIII SMP Negeri 2 Singaraja Tahun Ajaran 2016 - 2017, sedangkan sisanya 0.925 (92.5\%) dipengaruhi faktor lain yang tidak diungkapkan dalam penelitian ini.
\end{abstract}

Kata kunci: Hasil Belajar, Kontribusi, Perpustakaan

\begin{abstract}
This report aims to understand ( 1 ) the relationship between the use of the school library of the results of the study ips on a student viii smpn 2 singaraja academic year 2016-2017, and ( 2 ) the contribution of the school library of the results of the study ips on a student viii smpn 2 singaraja academic year 2016 2017. This research is the kind of research correlational .Data were collected with the documentation, the questionnaire, and observation. A subject in this study graders viii 1 viii 6 smpn singaraja 2 .An analysis of the data used was correlation analysis product moment, and coefficients determination $\left(R^{2}\right)$. The result showed that $(1)$ is no link positive correlation between the use of the school library on the learning science social (ips) on a student viii smpn 2 singaraja academic year 2016 2017. It can be seen from the rhitung $0.274>$ rtabel 0.1637 with a $5 \%$ significance. ( 2 ) contribution to use the school library ( $x$ ) of the results of the study (ips) he was in 0.075 this means that the use of the school library links of $0.075(7.5 \%)$ of the results of the study ips on a student viii smpn 2 singaraja academic year 2016 2017, the remaining 0.925 ( $92.5 \%$ ) other factors not expressed in this research
\end{abstract}

Keywords : Contribution, Learning Outcome, Library 


\section{PENDAHULUAN}

Pendidikan akan berjalan dengan baik bila didukung oleh fasilitas yang menunjang kegiatan pembelajaran, sehingga tujuan dari pembelajaran tersebut akan tercapai dengan baik pula. Pendidikan tidak mungkin dapat terselenggara dengan baik bila para tenaga kependidikan, tenaga pendidik, maupun siswa tidak di dukung oleh fasilitas pendukung pembelajaran yang memadai.

\begin{tabular}{lrr}
\multicolumn{1}{c}{ Satu } & diantara & fasilitas yang \\
diperlukan & dalam & menunjang \\
pembelajaran & adalah & perpustakaan.
\end{tabular}
Perpustakaan menyediakan berbagai koleksi buku-buku pelajaran dan berbagai koleksi buku-buku lainnya yang relevan dengan pembelajaran di sekolah. Dengan adanya perpustakaan, akan membuat para tenaga pendidik dan siswa memperoleh kesempatan untuk memperluas dan memperdalam pengetahuan yang diperlukan.

Smith dkk dalam buku ensiklopedianya yang berjudul The Educator's Encyclopedia (dalam Bafadal, 2005:6) menyatakan "School library is a center learning", artinya perpustakaan sekolah itu merupakan pusat belajar. Memang apabila ditinjau secara umum, perpustakaan sekolah itu sebagai pusat belajar, sebab kegiatan yang paling tampak pada setiap kunjungan siswa ke perpustakaan adalah belajar, baik belajar masalah-masalah yang berhubungan langsung dengan mata pelajaran yang diberikan dikelas, maupun buku-buku lain yang tidak ada hubungannya dengan mata pelajaran. Bila ditinjau dari sudut tujuan murid-murid mengunjungi perpustakaan sekolah, maka ada yang tujuannya untuk belajar, ada yang tujuannya untuk berlatih menelusuri buku-buku perpustakaan sekolah, ada yang tujuannya untuk memperoleh informasi, bahkan mungkin ada juga murid yang mengunjungi perpustakaan sekolah dengan tujuan hanya sekedar untuk mengisi waktu senggangnya atau sifatnya rekreatif.

Perpustakaan sebagaimana yang ada dan berkembang sekarang telah dipergunakan sebagai salah satu pusat informasi, sumber ilmu pengetahuan, penelitian, rekreasi, pelestarian khasanah budaya bangsa, serta memberikan berbagai layanan jasa lainnya. Hal tersebut telah ada sejak dulu dan terus berproses secara alamiah menunjuk kepada suatu kondisi dan tingkat perbaikan yang signifikan meskipun belum memuaskan semua pihak. Perpustakaan pada prinsipnya mempunyai tiga kegiatan pokok, yaitu pertama, mengumpulkan (to collect) semua informasi yang sesuai dengan bidang kegiatan dan misi organisasi serta masyarakat yang dilayaninya. Kedua, melestarikan, memelihara, dan merawat seluruh koleksi perpustakaan, agar tetap dalam keadaan baik, utuh, layak pakai, dan tidak mudah rusak, baik karena pemakaiannya maupun karena usianya (to preserve). Ketiga, menyediakan dan menyajikan informasi untuk siap dipergunakan dan diberdayakan (to make available) seluruh koleksi yang dihimpun di perpustakaan untuk dipergunakan pemakaiannya.

Pemanfaatan perpustakaan oleh siswa sangat erat kaitannya dengan proses pembelajaran yang diselenggarakan oleh sekolah. Hal ini karena pola pengajaran yang disebut sebagai keterbukaan informasi untuk memperoleh sebanyak-sebanyaknya ilmu pengetahuan hanya akan terlaksana jika siswa dapat memanfaatkan perpustakaan. $\mathrm{Di}$ kalangan siswa ada juga yang tidak memanfaatkan perpustakaan dalam menunjang proses belajarnya karena merasa bahwa pelajaran yang diberikan oleh guru sudah mencukupi. Selain itu, kurangnya tugas-tugas mandiri dari guru menyebabkan siswa tidak termotivasi untuk pergi berkunjung ke perpustakaan untuk menelaah dan mencari bahan pelajaran. Sekolah Menengah Pertama (SMP) Negeri 2 Singaraja memiliki perpustakaan yang dikelola oleh pihak SMP Negeri 2 Singaraja. Berbagai fasilitas dan layanan yang tersedia di perpustakaan yaitu buku pelajaran, buku cerita, novel, dan surat kabar.

Dalam kaitannya dengan pelajaran IImu Pengetahuan Sosial (IPS), peran perpustakaan menjadi penting karena sebagai sumber belajar selain guru. Kurang aktifnya siswa di kelas dalam 
pelajaran IImu Pengetahuan Sosial (IPS) biasanya disebabkan karena siswa kurang memahami materi pelajaran, hal ini karena siswa tidak pernah membaca buku. Dengan membaca siswa dapat melatih kemampuan berpikir, meningkatkan pemahaman, menambah wawasan dan ilmu pengetahuan, mendukung kemampuan berbicara di depan umum, dan meningkatkan konsentrasi

Berdasarkan hasil penelitian awal, tidak semua siswa memiliki skor hasil belajar yang sama dan kebiasaan belajar yang sama pada umumnya. Demikian pula dalam belajar memiliki kebiasaan yang berbeda-beda. Sebagian siswa memiliki kebiasaan belajar dengan datang ke perpustakaan, sedangkan sebagian lagi tidak. Hal ini terlihat dari sedikitnya kunjungan yang tercatat pada buku kunjungan siswa tiap harinya, yakni sebanyak $2,65 \%$ atau hanya enam orang dari 226 siswa kelas VIII 1 - VIII 6. Penyebab lainnya yaitu guru- guru di sekolah kurang intensif memotivasi siswa untuk memanfaatkan perpustakaan dalam proses pembelajaran yang mereka lakukan sehingga kunjungan siswa ke perpustakaan menjadi sangat rendah.

Berdasarkan fenomena di atas maka peneliti tertarik melakukan penelitian tentang "Kontribusi Pemanfaatan Perpustakaan Sekolah Terhadap Hasil Belajar IImu Pengetahuan Sosial (IPS) Pada Siswa Kelas VIII SMP Negeri 2 Singaraja Tahun Ajaran 2016 - 2017".

Berdasarkan latar belakang di atas, maka dapat dirumuskan permasalahan dalam penelitian ini, sebagai berikut. (1) Adakah hubungan antara pemanfaatan perpustakaan terhadap hasil belajar IPS pada siswa kelas VIII SMP Negeri 2 Singaraja Tahun Ajaran 20162017?(2)Bagaimana kontribusi pemanfaatan perpustakaan sekolah terhadap hasil belajar IPS pada siswa kelas VIII SMP Negeri 2 Singaraja Tahun Ajaran 2016- 2017?

Berdasarkan rumusan masalah tersebut maka dapat disusun tujuan dari penelitian ini. (1) Untuk mengetahui hubungan antara pemanfaatan perpustakaan sekolah terhadap hasil belajar IPS pada siswa kelas VIII SMP
Negeri 2 Singaraja tahun ajaran 20162017 (2) Untuk mengetahui kontribusi perpustakaan sekolah terhadap hasil belajar IPS pada siswa kelas VIII SMP Negeri 2 Singaraja tahun ajaran 2016 2017

Adapun manfaat yang diharapkan dari melakukan penelitian ini adalah sebagai berikut. 1 manfaat teoritis, (a) hasil penelitian ini diharapkan dapat memberikan manfaat bagi pengembangan perpustakaan di sekolah. 2 manfaat praktis, (a) hasil penelitian ini diharapkan dapat menambah sumber-sumber buku yang dapat menunjang pembelajaran sehingga guru dapat memberikan informasi yang lebih kepada siswa. (b) penelitian ini dapat meningkatkan pengetahuan siswa dan dapat membantu siswa dalam menyelesaikan tugas - tugas sekolah. (c) memberikan referensi bagi peneliti lain yang berminat dalam masalah yang serupa. (d)

hasil penelitian ini diharapkan dapat mewujudkan suatu wadah pengetahuan dengan administrasi dan organisasi yang sesuai sehingga memudahkan penggunanya serta dapat menyerap dan menghimpun informasi guna kegiatan belajar mengajar.

\section{METODE}

Jenis penelitian yang digunakan dalam penelitian ini adalah jenis penelitian korelasional. Menurut Siregar (2015:335) "analisis hubungan (korelasi) adalah suatu bentuk analisis data dalam penelitian yang bertujuan untuk mengetahui kekuatan atau bentuk arah hubungan di antara dua variabel dan besarnya pengaruh yang disebabkan oleh variabel yang satu terhadap variabel lainnya". Variabelvariabel yang dilibatkan dalam penelitian ini adalah (1) variabel pemanfaatan perpustakaan sekolah, dan (2) variabel hasil belajar.

Subjek dalam penelitian ini adalah siswa kelas VIII 1 - VIII 6 SMP Negeri 2 Singaraja. Sedangkan objek dalam penelitian ini adalah pemanfaatan perpustakaan sekolah dan hasil belajar IPS siswa kelas VIII SMP Negeri 2 Singaraja. 
Populasi pada penelitian ini adalah siswa kelas VIII 1 - VIII 6 SMP Negeri 2 Singaraja. Jumlah siswa kelas VIII adalah 226 siswa. Adapun data jumlah siswa kelas VIII 1- VIII 6 SMP Negeri 2 Singaraja, dapat dilihat pada tabel 1 sebagai berikut.

Tabel 3.1 Data Jumlah Siswa VIII 1 - VIII 6

\begin{tabular}{lll}
\hline No & Kelas & Jumlah Siswa \\
\hline 1. & VIII 1 & 38 \\
2. & VIII 2 & 38 \\
3. & VIII 3 & 38 \\
4. & VIII 4 & 38 \\
5. & VIII 5 & 37 \\
6. & VIII 6 & 37 \\
\hline & Jumlah & 226 \\
\hline
\end{tabular}

\section{Sumber: SMP Negeri 2 Singaraja}

Melihat jumlah siswa yang banyak maka dari sekian banyak jumlah populasi akan diambil sebagian untuk dijadikan sampel. Teknik pengambilan sampel yang akan digunakan dalam penelitian ini adalah propotional random sampling (undian) karena setiap anggota populasi yang ada di dalam kerangka sampling bersangkutan mempunyai kesempatan yang sama besar untuk dipilih menjadi anggota sampel.

Menurut Umar (2004) untuk menentukan sampel dari suatu populasi digunakan rumus Slovin sebagai berikut.

$$
\mathrm{n}=\frac{N}{1+N \cdot \mathrm{e}^{2}}
$$

Keterangan:

$\mathrm{n}=$ ukuran sampel

$\mathrm{N}=$ ukuran populasi

$\mathrm{e}=$ persen kelonggaran ketidaktelitian karena kesalahan pengambilan sampel

Perhitungan sampel dari jumlah populasi ditetapkan tingkat kebenaran atau kepercayaan $95 \%$ dan kesalahan sampel atau nilai kritis yang diinginkan sebesar 5\%. Berdasarkan rumus Slovin, maka jumlah sampel yang akan digunakan dalam penelitian ini dapat dihitung sebagai berikut.

$$
\begin{aligned}
& N=226 \\
& e=5 \% \\
& n=144,409
\end{aligned}
$$

Setelah dilakukan perhitungan tersebut, maka dari jumlah populasi sebanyak 226 siswa, diperoleh sampel sebanyak 144,409 (dibulatkan menjadi 144 orang) sesuai dengan teknik yang digunakan yaitu proporsional random sampling, maka dapat dilakukan perhitungan besarnya sampel tiap-tiap kelas dari sampel siswa kelas VIII 1-VIII 6 sebagai berikut.

1. Kelas VIII 1, VIII 2, VIII 3, dan VIII 4

$$
\text { (38 orang) } \frac{38}{226} \times 144=24 \text { orang }
$$

2. Kelas VIII 5 dan VIII 6 (37 orang)

$$
\frac{8 \pi}{226} \times 144=24 \text { orang }
$$

Untuk lebih mudah melihat jumlah pembagian sampel tiap kelasnya dalam penelitian ini dapat dilihat dalam tabel 2 sebagai berikut.

\section{Tabel 2 Jumlah Sampel Penelitian Tiap Kelas}

\begin{tabular}{ccc}
\hline No & Kelas & Jumlah Sampel \\
\cline { 2 - 3 } 1. & VIII 1 & 24 Orang \\
2. & VIII 2 & 24 Orang \\
3. & VIII 3 & 24 Orang \\
4. & VIII 4 & 24 Orang \\
5. & VIII 5 & 24 Orang \\
6. & VIII 6 & 24 Orang \\
\hline
\end{tabular}


Jenis data dalam penelitian ini adalah data kuantitatif dan data kualitatif. Data kuantitatif adalah data yang dapat dihitung dan berupa angka-angka. Sedangkan data kualitatif adalah data berbentuk kalimat. Data kuantitatif dalam penelitian ini adalah hasil belajar IPS siswa kelas VIII 1 - VIII 6 SMP Negeri 2 Singaraja. Sedangkan data kualitatif dalam penelitian ini adalah pemanfaatan perpustakaan sekolah.

Sumber data yang diperoleh adalah data primer berupa skor responden terhadap angket pemanfaatan perpustakaan sekolah dengan indikator membaca buku yang berkaitan dengan materi pelajaran, kelengkapan buku di perpustakaan, inisiatif siswa berkunjung ke perpustakaan, usaha siswa melengkapi materi pelajaran, kenyamanan siswa saat berdiskusi di perpustakaan, dan mencari materi tambahan di perpustakaan guna mendiskusikannya. Data sekunder berupa data jumlah siswa kelas VIII 1 - VIII 6, hasil belajar IPS yang diperoleh dari guru IPS SMP Negeri 2 Singaraja dan data jumlah kunjungan siswa kelas VIII 1 - VIII 6 ke perpustakaan sekolah.

Metode pengumpulan data yang digunakan dalam penelitian ini adalah metode angket. Skala yang digunakan dalam angket adalah Skala Likert. Kategori penskoran angket dengan skala likert dapat dilihat pada tabel 3 sebagai berikut.

Tabel 3 Penskoran Angket

\begin{tabular}{lcc}
\hline No. & Skala & Kategori \\
\hline 1. & 5 & Sangat setuju \\
2. & 4 & Setuju \\
3. & 3 & Cukup setuju \\
4. & 2 & Tidak setuju \\
5. & 1 & Sangat tidak setuju \\
\hline
\end{tabular}

Sumber: Siregar, 2015.

Metode dokumentasi digunakan untuk memperoleh data hasil belajar IPS siswa kelas VIII 1 - VIII 6 di SMP Negeri 2 Singaraja, dan metode observasi digunakan untuk melengkapi data yang diperoleh dari penyebaran angket ke responden tentang pemanfaatan perpustakaan sekolah oleh siswa kelas VIII di SMP Negeri 2 Singaraja.

Uji validitas dalam penelitian ini diuji dengan analisis butir yaitu menggunakan kesesuaian antara butir-butir pertanyaan terhadap keseluruhan instrumen. Valid tidaknya setiap butir pertanyaan diperoleh dengan cara mengkorelasi jumlah skor butir dengan skor total.

Kriteria yang digunakan adalah dengan membandingkan harga $r_{x y}$ dengan harga tabel apabila $r_{x y}>r_{\text {tabel }}$ pada $\alpha=0,05$. Untuk menghitung validitas butir digunakan program SPSS 16.0. Nilai validitas untuk setiap butir instrumen ditetapkan batas terendah 0,361. Pengambilan keputusan tentang ketepatan setiap butir instrumen ditentukan dari nilai $r$ hasil setiap item pada kolom correlated item. Jika $r$ hasil positif dan lebih besar dari $r$ batas $(0,361)$, maka butir tersebut dinyatakan valid.

Pengujian reliabilitas berkaitan dengan masalah adanya kepercayaan terhadap instrumen penelitian. Apabila instrumen menggunakan skala likert, indeks keterhandalannya dapat dihitung dengan menggunakan koefisien Crombach Alpha.

Dalam penelitian ini pengujian reliabilitas instrumen akan diolah dengan menggunakan SPSS 16.0 yaitu dengan membandingkan nilai Crombach Alpha yang diperoleh dari SPSS 16.0 dengan batas nilai Crombach Alpha untuk mengukur instrumen yang reliabel. Pengujian statistik dengan menggunakan teknik statistik Crombach Alpha, instrumen dikatakan reliabel untuk mengukur variabel apa apabila memiliki nilai Crombach Alpha lebih besar dari 0,60. 
Teknik analisis data yang digunakan dalam penelitian ini adalah korelasi product moment untuk mengetahui besaran hubungan antara pemanfaatan perpustakaan sekolah (X) dan hasil belajar IPS (Y) dan koefisien determinasi. Koefisien determinasi adalah angka yang menyatakan atau digunakan untuk mengetahui kontribusi atau sumbangan yang diberikan oleh sebuah variabel $\mathrm{X}$ terhadap variabel $\mathrm{Y}$.

Untuk memberikan besarnya tingkat hubungan antara kedua variabel, dapat dilihat pada tabel 4 .

Tabel 4. Besarnya Tingkat Hubungan

\begin{tabular}{lll}
\hline No & Nilai Korelasi $(r)$ & Tingkat Hubungan \\
\hline 1. & $0,00-0,199$ & Sangat lemah \\
2. & $0,20-0,399$ & Lemah \\
3. & $0,40-0,599$ & Cukup \\
4. & $0,60-0,799$ & Kuat \\
5. & $0,80-0,100$ & Sangat Kuat \\
\hline
\end{tabular}

Sumber: Siregar (2015:337)

\section{HASIL DAN PEMBAHASAN Hasil Penelitian}

Berdasarkan hasil analisis data untuk mencari hubungan pemanfaatan perpustakaan sekolah terhadap hasil belajar IImu Pengetahuan Sosial (IPS) Pada Siswa Kelas VIII SMP Negeri 2 Singaraja Tahun Ajaran 2016 - 2017 yang tercantum pada tabel 5 sebagai berikut.

Tabel 5 Hasil Korelasi Product Moment dengan uji Pearson Correlation Correlations

\begin{tabular}{|c|c|c|c|}
\hline & & $\begin{array}{l}\text { Pemanfaatan } \\
\text { perpustakaan } \\
\text { sekolah }\end{array}$ & Hasil Belajar IPS \\
\hline \multirow{3}{*}{$\begin{array}{l}\text { Pemanfaatan } \\
\text { sekolah }\end{array}$} & perpustakaan Pearson Correlation & 1 & $.274^{* *}$ \\
\hline & Sig. (2-tailed) & & .001 \\
\hline & $\mathrm{N}$ & 144 & 144 \\
\hline \multirow[t]{3}{*}{ Hasil Belajar IPS } & Pearson Correlation & $.274^{* *}$ & 1 \\
\hline & Sig. (2-tailed) & .001 & \\
\hline & $\mathrm{N}$ & 144 & 144 \\
\hline
\end{tabular}

Sumber: Data SPSS versi 16.00

Berdasarkan hasil analisis data menunjukan bahwa nilai hubungan $\left(r_{x y}\right)$ antara pemanfaatan perpustakaan sekolah terhadap hasil belajar IImu Pengetahuan Sosial (IPS) diperoleh $r_{\text {hitung }}$ $0.274>r_{\text {tabel }} 0.1637$ dengan tingkat signifikansi $5 \%$ maka hipotesis nihil $(\mathrm{H} 0)$ ditolak dan hipotesis alternative $(\mathrm{Ha})$ diterima sehingga ada hubungan (korelasi) yang positif antara pemanfaatan determinasi ganda $\left(R^{2}\right)$ dapat dilihat pada tabel 6 . perpustakaan sekolah terhadap hasil belajar IImu Pengetahuan Sosial (IPS) pada siswa kelas VIII SMP Negeri 2 Singaraja Tahun Ajaran 2016-2017. Untuk mengetahui kontribusi pemanfaatan perpustakaan sekolah terhadap hasil belajar IPS pada siswa kelas VIII SMP Negeri 2 Singaraja tahun ajaran 2016 - 2017 digunakan analisis determinasi $\left(R^{2}\right)$. Perhitungan koefisien 


\section{Tabel 6 hasil perhitungan koefisien determinasi $\left(\mathbf{R}^{2}\right)$ Model Summary}

\begin{tabular}{|c|c|c|c|c|c|c|c|c|c|}
\hline $\begin{array}{c}\text { Mod } \\
\text { el }\end{array}$ & R & $\begin{array}{c}R \\
\text { Squar } \\
e\end{array}$ & $\begin{array}{l}\text { Adjusted } \\
\text { R Square }\end{array}$ & $\begin{array}{l}\text { Std. Error } \\
\text { of the } \\
\text { Estimate }\end{array}$ & $\begin{array}{l}\text { R Square } \\
\text { Change }\end{array}$ & $\begin{array}{l}\text { Chan } \\
\text { F } \\
\text { Chang } \\
\text { e }\end{array}$ & e Sta & stics & $\begin{array}{c}\text { Sig. } F \\
\text { Change }\end{array}$ \\
\hline 1 & $.274^{a}$ & .075 & .068 & 4.40257 & .075 & 11.499 & 1 & 142 & .001 \\
\hline
\end{tabular}

Sumber: Data SPSS versi 16.00

Berdasarkan hasil analisis pada tabel 6 menunjukkan kontribusi pemanfaatan perpustakaan sekolah $(X)$ terhadap hasil belajar IPS $(Y)$ adalah sebesar 0.075 hal ini berarti pemanfaatan perpustakaan sekolah memiliki hubungan sebesar 0.075 $(7.5 \%)$ terhadap hasil belajar IPS pada siswa kelas VIII SMP Negeri 2 Singaraja Tahun Ajaran 2016 - 2017, sedangkan sisanya $0.925(92.5 \%)$ dipengaruhi faktor lain yang tidak diungkapkan dalam penelitian ini.

\section{Pembahasan}

Berdasarkan hasil penelitian menunjukkan bahwa ada hubungan antara pemanfaatan perpustakaan sekolah terhadap hasil belajar Ilmu Pengetahuan Sosial (IPS) pada siswa kelas VIII SMP Negeri 2 Singaraja Tahun Ajaran 2016 2017. Hal ini ditujukkan dengan hasil yang diperoleh $r_{\text {hitung }} 0.274>r_{\text {tabel }} 0.1637$ dengan tingkat signifikansi $5 \%$. Hasil penelitian ini mendukung hasil temuan teoritik dari (Djamarah 2002) bahwa faktor sarana dan fasilitas seperti perpustakaan sekolah mempengaruhi proses dan hasil belajar siswa. Perpustakaan sekolah merupakan laboratorium ilmu, tempat ini harus menjadi sahabat karib siswa demi keberhasilan belajar dan juga sebagai fasilitator, mediator serta motivator bagi mereka yang ingin mencari, memanfaatkan dan mengembangkan ilmu pengetahuan dan pengalamannya.

Berdasarkan analisis pada tabel 6 menunjukkan kontribusi pemanfaatan perpustakaan sekolah $(\mathrm{X})$ terhadap hasil belajar IPS (Y) adalah sebesar 0.075 hal ini berarti pemanfaatan perpustakaan sekolah memiliki hubungan sebesar 0.075 (7.5\%) terhadap hasil belajar IPS pada siswa kelas VIII SMP Negeri 2 Singaraja Tahun Ajaran 2016 - 2017, sedangkan sisanya $0.925(92.5 \%)$ dipengaruhi faktor lain yang tidak diungkapkan dalam penelitian ini. Hal ini menunjukan bahwa pemanfaatan perpustakaan sekolah bukanlah merupakan satu-satunya yang mempengaruhi hasil belajar siswa.

\section{SIMPULAN DAN SARAN Simpulan}

Berdasarkan hasil analisis data pada bab IV, maka dapat dibuat simpulan halhal sebagai berikut.

Ada hubungan antara pemanfaatan perpustakaan sekolah terhadap hasil belajar IImu Pengetahuan Sosial (IPS) pada siswa kelas VIII SMP Negeri 2 Singaraja Tahun Ajaran 2016 - 2017. Hal ini ditujukan dengan hasil yang diperoleh $r_{\text {hitung }} 0.274>r_{\text {tabel }} 0.1637$ dengan tingkat signifikansi $5 \%$ maka hipotesis nihil ( $\mathrm{HO})$ ditolak dan hipotesis alternatif $(\mathrm{Ha})$ diterima.

Kontribusi pemanfaatan perpustakaan sekolah $(\mathrm{X})$ terhadap hasil belajar IPS $(\mathrm{Y})$ adalah sebesar 0.075 hal ini berarti pemanfaatan perpustakaan sekolah memiliki hubungan sebesar 0.075 (7.5\%) terhadap hasil belajar IPS pada siswa kelas VIII SMP Negeri 2 Singaraja Tahun Ajaran 2016 - 2017, sedangkan sisanya 0.925 (92.5\%) dipengaruhi faktor lain yang tidak diungkapkan dalam penelitian ini. 


\section{Saran}

Berdasarkan temuan hasil penelitian yang telah dibahas pada BAB IV dan dari penarikan beberapa kesimpulan di atas maka dapat diajukan beberapa saran sebagai berikut. 1 bagi siswa (a) diharapkan dapat memanfaatkan fasilitas yang telah disediakan seperti perpustakaan sekolah. Perpustakaan sekolah merupakan salah satu sarana dan sumber belajar bagi siswa dalam memperoleh informasi. Dengan pemanfaatan perpustakaan yang baik oleh siswa maka siswa dapat meningkatkan hasil belajar. 2 bagi sekolah (a) diharapkan kedepannya dapat mengembangkan perpustakaan sekolah dan melengkapi sarana belajar siswa seperti buku-buku yang sesuai dengan kebutuhan siswa dalam memperoleh informasi dalam meningkatkan hasil belajar siswa. 3 bagi peneliti, (a) selanjutnya diharapkan dapat menambahkan variabel yang menyangkut aspek tersebut untuk lebih mengetahui variabel-variabel yang mempengaruhi penelitian ini.

\section{DAFTAR PUSTAKA}

Ahla, Fiana. 2015. Pengertian dan Jenis Penelitian. Tersedia pada http://artikelilmiahlengkap.blogsp ot.co.id/2015/08/pengertian-danjenis-penelitian.html (diakses tanggal 21 Agustus 2016)

\section{Ati, Asmi. 2013. Pengadaan Bahan Pustaka. Tersedia pada http://asmi- ati.blogspot.co.id/2013/11/penga daan-bahan-pustaka (diakses tanggal 27 April 2016)}

Bafadal, Ibrahim. 2003. Manajemen Perlengkapan Sekolah Teori dan Aplikasinya. Jakarta: PT Bumi Aksara

\section{Pengelolaan}

Perpustakaan Sekolah. Jakarta: PT Bumi Aksara

Dimyati dan Mudjiono. 2006. Belajar dan Pembelajaran. Jakarta: PT Rineka Cipta

Djamarah, Bahri. 2002. Psikologi Belajar. Jakarta: PT Rineka Cipta

Firdaus, Aziz. 2012. Metode Penelitian. Tangerang: Jelajah Nusa

Hamalik. 2004. Proses Belajar

Mengajar. Jakarta: PT Bumi Aksara

Imran. 2014. Peran dan Tugas Perpustakaan. Tersedia pada http://ilmupendidikan.net/pustaka/perpusta kaan/peran-tugas-perpustakaan (diakses tanggal 27 April 2016)

Komariah. 2010. Peranan Perpustakaan Sekolah Dalam Proses Belajar Mengajar. Tersedia pada http://pustaka.unpad.ac.id/wpcont ent/uploads/2010/peranan perpu stakaan sekolah.pdf. (diakses tanggal 27 April 2016)

Lukman. 2015. Landasan Hukum Berdirinya Perpustakaan Sekolah. Tersedia pada http://ebesblog.com/perpustakaa n/buku-ajar-perpustakaan (diakses tanggal 27 April 2016)

Mansyur. 2016. Manajemen Perpustakaan Sekolah. Tersedia pada http://jurnal.stainponorogo.ac.id/i ndex.php/pustakaloka/article/dow nload/184/155. (diakses tanggal 27 April 2016)

Mulyana. 2012. Pengertian dan Faktor Hasil Belajar. Tersedia pada http://ainamulyana.blogspot.co.id/ 2012/01/pengertian-hasil-belajardan-faktor.html (diakses tanggal 27 April 2016)

Noreng, Ignatius. 2013. Pengaruh Pemanfaatan Perpustakaan Sekolah Terhadap Hasil Belajar IPS Siswa SMP Negeri 18 Pontianak. Tersedia pada http://jurnal.untan.ac.id/index.php 
/ipdpb/article/download/1382/pdf (diakses tanggal 18 April 2016)

Prastowo, Andi. 2012. Manajemen Perpustakaan Sekolah Profesional. Yogyakarta: Diva Press

Prayantini, Dianti. 2014. Pengaruh Pemanfaatan Perpustakaan Undiksha Dalam Menunjang Prestasi Belajar Mahasiswa Pendidikan Ekonomi Universitas Pendidikan Ganesha Angkatan 2010-2012. Tersedia pada http://ejournal.undiksha.ac.id/ind ex.php/JJPE/article/view/2023 (diakses tanggal 18 April 2016)

Puji, Lestari. 2012. Pengelolaan Perpustakaan Sekolah. Tersedia pada

http://cakrukilmu.blogspot.co.id/2 012/01/pengelolaanperpustakaan-sekolah.html (diakses tanggal 27 April 2016)

Riana, Dwiza. 2012. Statistika Deskriptif Itu Mudah. Tangerang: Jelajah Nusa

Rochman. 2011. Kontribusi Pemanfaatan Perpustakaan Kemampuan Terhadap Menyelesaikan Tugas-Tugas Pada Mata Diklat Menggambar Konstruksi Kayu Di SMKN 6 Bandung. Tersedia pada http://repository.upi.edu/pdf (diakses tanggal 30 April 2016)

Rohmansah. 2013. Hubungan Pemanfaatan Perpustakaan Sekolah Dengan Hasil Belajar Siswa Di SMP Negeri 1 Siwalan Kabupaten Pekalongan Semester Gasal Tahun Ajaran 2012-2013. Tersedia pada http://lib.unnes.ac.id/19924/1/32 01406502.pdf. (diakses tanggal $\overline{27 \text { April 2016) }}$

Siregar, Syofian. 2015. Statistik Parametrik Untuk Penelitian
Kuantitatif. Jakarta: PT Bumi Aksara

Sudjana, Nana. 2006. Penilaian Hasil Proses Belajar Mengajar. Bandung: PT Remaja Rosdakarya

Surachman, Arif. 2011. Manajemen Perpustakaan Sekolah. Tersedia pada

http://arifs.staff.ugm.ac.id/pdf (diakses tanggal 27 April 2016)

Sutarno. 2006. Perpustakaan dan

Masyarakat. Jakarta: CV Sagung Seto

Umar, Husein. 2004. Metode Penelitian Untuk Skripsi dan Tesis Bisnis. Jakarta: PT Raja Grafindo Persada

Wahyudi. 2014. Hasil belajar. Tersedia pada

http://digilib.uinsby.ac.id/779/3/B ab\%202.pdf (diakses tanggal 27 April 2016)

Widayati, Genda. 2007. Kontribusi Pemanfaatan Perpustakaan Terhadap Hasil Belajar Biologi Pada Siswa Kelas VIII Semester Ganjil Tahun Pelajaran 20052006 SMP Negeri 1 Kalikotes Klaten. Tersedia pada http://eprints.ums.ac.id/11028/3/ 1 .pdf (diakses tanggal 18 April 2016)

Wiyandari, Asri. 2014. Pengaruh Pemanfaatan Perpustakaan Sekolah Terhadap Hasil Belajar Akuntansi $X$ AK Di SMKN 1 Pontianak. Tersedia pada http://jurnal.untan.ac.id/index.php /jpdpb/article/viewFile/6430/6643 (diakses tanggal 18 April 2016)

Yulianti. 2014. Perpustakaan Keliling. Tersedia pada

http://repository.usu.ac.id/ bitstream/123456789/41297/4/Ch apter\%20ll.pdf. (diakses tanggal 21 Agustus 2016) 